IZA DP No. 8703

The Impact of the Minimum Wage on Match Stability

Mário Centeno

Cláudia Duarte

Álvaro A. Novo

December 2014

Forschungsinstitut

zur Zukunft der Arbeit

Institute for the Study

of Labor 


\title{
The Impact of the Minimum Wage on Match Stability
}

\author{
Mário Centeno \\ Banco de Portugal, ISEG, IZA and ISEGI
}

Cláudia Duarte

Banco de Portugal

Álvaro A. Novo

Banco de Portugal, Universidade Lusófona and IZA

\author{
Discussion Paper No. 8703 \\ December 2014
}

\author{
IZA \\ P.O. Box 7240 \\ 53072 Bonn \\ Germany \\ Phone: +49-228-3894-0 \\ Fax: +49-228-3894-180 \\ E-mail: iza@iza.org
}

\begin{abstract}
Any opinions expressed here are those of the author(s) and not those of IZA. Research published in this series may include views on policy, but the institute itself takes no institutional policy positions. The IZA research network is committed to the IZA Guiding Principles of Research Integrity.

The Institute for the Study of Labor (IZA) in Bonn is a local and virtual international research center and a place of communication between science, politics and business. IZA is an independent nonprofit organization supported by Deutsche Post Foundation. The center is associated with the University of Bonn and offers a stimulating research environment through its international network, workshops and conferences, data service, project support, research visits and doctoral program. IZA engages in (i) original and internationally competitive research in all fields of labor economics, (ii) development of policy concepts, and (iii) dissemination of research results and concepts to the interested public.
\end{abstract}

IZA Discussion Papers often represent preliminary work and are circulated to encourage discussion. Citation of such a paper should account for its provisional character. A revised version may be available directly from the author. 
IZA Discussion Paper No. 8703

December 2014

\section{ABSTRACT}

\section{The Impact of the Minimum Wage on Match Stability}

We explore increases in the nominal minimum wage in a difference-in-differences setting to estimate match survival wage elasticity. The elasticity is negative and larger than one for matches directly affected by minimum wage increases, those with paying below the new minimum wage. The impact of the minimum wage is stronger for young workers and the manufacturing sector, groups with a large and increasing share of low-wage workers. Given the low-wage mobility in the Portuguese labor market and the large share of workers directly affected by the minimum wage increase (reaching almost 18\%), these results call for a careful analysis of the set of policies that interfere with low-wage employment.

JEL Classification: J23, J38

Keywords: minimum wage, employment and match elasticities, spillover

Corresponding author:

Mário Centeno

Banco de Portugal

Economics Department

Av. Almirante Reis, 71-6

1150-012 Lisbon

Portugal

E-mail: mcenteno@bportugal.pt 


\section{Introduction}

The impact of the minimum wage has been analyzed mainly from the point of view of employment outcomes: are workers able to secure employment? However, many theoretical models consider worker-firm relationships in a job-search environment (Pissarides 2000). In tandem with these theories, labor economics has been placing more emphasis on the behavior of matches. Therefore, in this paper, we focus on the impact of the minimum wage on match survival and wages, decisions typical of internal labor markets (Lazear and Shaw 2007).

The impact of the minimum wage on a worker's career is better captured in match survival. Low-wage matches, because they are more likely to be low-quality jobs, are easier to terminate (Jovanovic 1979, Topel and Ward 1992). As a result, minimum wage may have a non-trivial role in promoting rotation at the low-end of the wage distribution. With risk-averse workers, the uncertainty arising from minimum wage increases may be detrimental for overall welfare (Flinn 2010). But the general equilibrium effects are undetermined. A larger minimum wage may increase welfare if it pushes firms and workers to create and look for higher quality jobs (Acemoglu 2001).

We analyze the impact of minimum wage policy in Portugal between 2002 and 2010, a period with substantial nominal minimum wage increases. We study how the interaction of the (real) minimum wage variation and the worker's position in the distribution of wages affects the probability of match survival and wage. We also study the probability that the worker retains employment. We define a treatment and a control group and apply a difference-indifferences strategy. The treatment group includes all matches directly and indirectly affected by the minimum wage increase. The former includes matches paying less than the new minimum wage and the latter includes the remaining matches up to the 3rd quartile of the wage distribution. The control group includes all matches not affected by the minimum wage increase, by assumption those in the 4th quartile.

We obtain minimum wage elasticities larger than one for matches paying less than the new minimum wage. Changes in the minimum wage affect more strongly employment and wages at the match level, than if there is a change in employer. The impact on wages and employment stability complement each other and are the expected outcome along a labor demand schedule.

The textbook treatment of the minimum wage posits a negative impact on employment, 
but it is also recognized that the minimum wage can have a positive impact under labor market frictions and/or multiple equilibrium (Flinn 2010). In practice, as pointed out by Freeman (1996), research consensus for the impact of the minimum wage on employment is a debate around zero. The empirical evidence shows that the initial level and the dimension of the increase in the minimum wage seem to be relevant to set the case. These empirical regularities come from country studies showing that when the minimum wage is "low" relative to the median wage, it has a small negative or even positive impact on employment (Card and Krueger 1995, Neumark, Schweitzer and Wascher 2004, Dube, Lester and Reich 2010). In contrast, a minimum wage that is "high", most notably in France or in some sectors in Germany, is associated with a large disemployment effect (Abowd, Kramarz, Margolis and Philippon (2000) or Kramarz and Philippon (2001) for France and König and Möller (2009) for Germany).

The minimum wage changes the relative price of workers inside the firm, making those better paid relatively less expensive. This may drive employment away from minimum wage earners, but it may also result in a significant compression of the wage distribution. The latter generates a negative spillover, in the form of a ripple effect, that sets smaller wage increases for workers earning just above the new minimum wage (Neumark et al. 2004, Autor, Manning and Smith 2010).

We find evidence consistent with a ripple effect. In Portugal, large updates of the minimum wage lead to a reduction in the wage increase of matches paying above the new minimum. This implies reductions in lower-tail wage inequality, which are made larger by the reduction in low-wage employment. The minimum wage seems to be binding in the behavior of workers and firms, but the goal of increasing the incomes of low-income workers comes at a cost. Directly for those not securing employment and indirectly through constrained wage progression.

The policy lessons from the Portuguese experience may be relevant for other economies. First, raising the minimum wage may discourage firms from creating low-wage jobs targeted at low-skilled workers. Second, the disemployment effect of the minimum wage can be larger than its direct impact on wages, resulting in a wage elasticity smaller than -1 . Third, lower match stability can generate a reduction in training and work experience due to excessive worker rotation. Minimum wage policy should be used with caution as the consequence of these risks is a reduction in lower wage mobility. 


\section{Data}

We use Social Security records, a matched employer-employee longitudinal database made available by Instituto de Informática da Segurança Social (the Portuguese social security data processing office). The dataset includes all workers with wages and contributions reported to the social security public system from 2002 to 2010. One of the main advantages of this dataset to study wages is its mandatory nature, which arises from the fact that all public related transfers (e.g. pensions, unemployment and disability subsidies) are paid according to the contributory records.

The information on wages refers to the gross monthly values, reported in October of each year. The wage measure includes all types of compensation, namely permanent wage, variable components - such as overtime and premiums, two subsidies paid in Portugal in mid-year and at the end of the year, and seniority-related payments.

The database also includes information on job tenure, gender, age and employment status - employees, self-employed or other -, region, firm size, and activity sector. The coverage of public administration and financial services is limited because these sectors have had their own social security systems.

We restrict the dataset to salaried workers, whose wage is at least the minimum wage. To avoid slight differences due to rounding, we considered that an employee earned the minimum wage if its base wage falls in a 2-euro interval centered on the legal minimum wage (minimum wage $+/-1$ euro). Furthermore, inconsistent and missing reports on gender, age and job tenure are dropped.

The sample has almost 25 million year $\times$ worker $\times$ firm observations, an average of 2.7 million matches each year.

\section{The evolution of minimum wage in Portugal}

The Portuguese minimum wage legislation introduced in 1974, defined the legal minimum wage for employees with at least 20 years of age, exempting agriculture, domestic work and firms with up to 5 workers. Since then, this legislation has undergone several adjustments and currently there are no exceptions by age, activity sector or firm size. The minimum wage is the same for all employees except apprentices and trainees (whose minimum wage can be 
reduced by $20 \%$ ) and disabled workers (reductions between $10 \%$ and $50 \%$ ). Developments in the minimum wage are discretionary, not following a formal rule or indexation. They are often included in national agreements signed by employers associations, unions and the government.

In the sample period, the rate of change of the minimum wage tracked expected inflation until 2006, resulting in changes of the real minimum wage close to zero (Figure 1). This situation changed as a result of the December 2006 5-year agreement aimed at raising the minimum wage from 385 euros to 500 euros by 2011.

FIGURE 1; see page 18.

The Kaitz index in Portugal stands out as one of the largest in Europe, but the pre- and post-agreement periods have quite distinct evolutions in the variables related to the minimum wage. In 2002 the minimum wage was 348 euros, representing $70 \%$ of the median wage (Table 1). Until 2006 this figure falls slightly, due to the small increase in the minimum wage, to 67\%. In 2009 the Kaitz index was already back at $70 \%$ and in 2010 it reached $72 \%$.

TABLE 1; see page 21.

The share of minimum wage earners remained fairly stable until 2006, at around $8 \%$, but since 2007 the share of minimum wage earners increased markedly, to reach $12.4 \%$ in 2010 . This evolution was common to groups defined by age, gender and sectors, being more striking for females and young workers and in manufacturing and the construction sectors (Table 1).

Economic theory predicts that an increase in the minimum wage shifts the wage distribution and destroys low-wage matches. It also predicts a fat tail of wages at the minimum wage as a result of the censoring of the wage distribution (Flinn 2010). The larger the increase in the minimum wage the sharper these effects would look like (Card and Krueger 1995). A simple visual inspection of the wage distribution confirms these predictions. First, note that the minimum wage is the mode of the distribution (Figure 2). Second, between 2006 and 2010, a significant fraction of the mass of workers with wages between 385 and 475 euros (the minimum wage in each of these years) was absorbed by the minimum wage. These workers were directly affected by increases in the minimum wage and will be key in our experimental design.

FIGURE 2; see page 18. 
Figure 3 presents simple evidence of the ripple effect in Card and Krueger (1995). It shows the rate of change of wages up to the 75 th percentile in 2004, when real the minimum wage remained unchanged, and in 2009, a period with the highest real change of the minimum wage. In 2004 (and similarly for the years prior to the minimum wage agreement), the wage growth is increasing over the wage distribution, reflecting turnover decisions and the existence of returns to tenure (Jovanovic 1979). In 2009 (and in all years with a large real minimum wage increase) wages grew more for low wage percentiles than they did for wage percentiles just above the new minimum wage.

FIGURE 3; see page 19.

The impact of the minimum wage is also observable in labor market transitions. Minimum wage workers represent a large share of the total number of workers that enter non-employment (Figure 4): 16\% until 2006 (and 8\% of total employment) and more than $22 \%$ afterwards (and $11 \%$ of total employment). As expected, match survival is larger at the high-end of the wage distribution. This follows from the learning process about match quality (Flinn 1986, Topel and Ward 1992). In our data, the likelihood of entering non-employment is 11 percentage points larger for minimum wage workers compared with workers above the first quartile of the wage distribution.

FIGURE 4; see page 19.

This analysis in complemented in Table 2 with a full account of the empirical transition probabilities as a function of the wage level. We define four groups: (i) wage equal to the old minimum wage; (ii) wage between the old and next year's minimum wage; (iii) wage in the first quartile, but higher than the new minimum; (iv) wage above the first quartile. We split the years into the two sub-periods defined by the minimum wage agreement and compute averages of year-to-year transition rates.

TABLE 2; see page 22.

Three main conclusions emerge. First, only a small fraction of the workers earning the minimum wage in a specific year move into a wage higher than the new minimum. This fraction was $25.3 \%$ in the first period, but fell to $21.8 \%$ in the years with stronger minimum wage increases. Second, the share of workers earning in period $t-1$ less than the new 
minimum wage that is exactly at the new minimum in $t$ is large. It averaged $25 \%$ until 2006 and $32 \%$ since 2007 . Together, these results suggest that large minimum wage increases result into lower wage mobility. Finally, the retention rate at the minimum wage is quite high and increases with the minimum wage, averaging $78 \%$ in the second period.

\section{Results}

The debate on the impact of the minimum wage on employment and, in general, in the economy and society, is one that will be ultimately settled by the empirical evidence. We estimate a set of models that analyze how the interaction between the real minimum wage increases and the worker position in the distribution of wages determines the probability that (s)he remains: (i) in the same match or (ii) employed.

We focus on how the stability of the employer-employee match is affected by changes in the minimum wage. This is new in the literature and goes well into the core of the minimum wage impact at the firm level. The exogenous shock coming from a minimum wage increase is more likely to affect the survival rate of matches than the probability of employment. In existing matches there is a set of constraints already in place that are harder to circumvent than in newly-created jobs. At the match level, we expect a more complete transmission of the minimum wage shock to wages and, along the firm demand schedule, to match destruction. The impact on employment is mitigated by the ability of workers to find an alternative job, which depends on the wage elasticity of labor supply and on labor demand by other firms.

\subsection{Methodology}

We model the impact of the minimum wage on match and employment survival following the methodology developed in Currie and Fallick (1996), Kramarz and Philippon (2001) and Neumark et al. (2004). This can be interpreted as a difference-in-differences evaluation strategy and to implement it we need to define treatment and control groups.

Let $m w_{t}$ be the nominal minimum wage at date $t$ and $m w_{t}>m w_{t-1}$ represent an increase in the nominal minimum wage in period $t$. All matches with wages below the new minimum wage, $w_{t}<m w_{t+1}$, are directly affected by the increase. But if the minimum wage has a ripple effect, then there is a group of workers indirectly affected by increases in the minimum wage. Similarly to Autor et al. (2010), we assume that only matches below the 75 th percentile 
of the wage distribution can be affected. The empirical model splits these matches in three groups: (i) those in the 1st quartile with wages above the new minimum; (ii) the 2nd quartile; and (iii) the 3rd quartile of the wage distribution. This allows the effects of the minimum wages to differ across the wage distribution, as in Neumark et al. (2004), which shows that there is no impact of the minimum wage on employment for wages above 1.5 minimum wages. Note that in our sample, the 3rd quartile of wages corresponds to around twice the minimum wage.

Finally, the control group is defined by all matches not affected by the minimum wage increase, those in the 4 th quartile of the wage distribution.

Splitting the treatment group in 5 groups adds flexibility to the specification, allowing for differentiated impacts. We can test the hypothesis that these are lower the further away a match is from the minimum wage.

We estimate two empirical models. First, we consider the following cross-sectional model, estimated for each year $t$ separately:

$$
y_{i t}=\sum_{k=1}^{6} \beta_{k} D_{k, i t-1}+X_{i t-1} \lambda+\varepsilon_{i t},
$$

where $y_{i t}$ assumes the value 1 if the match survives from year $t-1$ to $t$ and 0 if it is destroyed. The parameters of interest are the $\beta_{k} s$, which capture the effects of an increase in the minimum wage for each part of the wage distribution defined by the dummy variables $D_{k}$. As defined above, $D_{k, i t-1}$ are dummy variables that assume the value 1 if the wage in year $t-1$ is in one of the 6 following wage groups: (i) current minimum wage; (ii) less than next year's minimum wage; (iii) more than next year's minimum wage but less than 1st quartile; (iv) 2nd quartile; (v) 3rd quartile; (vi) 4th quartile, the control, left out as the reference group in the model estimation. The matrix $X_{i t-1}$ includes variables with worker, firm and match characteristics, namely: a quadratic term in the age of the worker; gender indicator; immigrant worker indicator; sector dummies (extractive; manufacturing; construction and services); firm size dummies (small: 1-25 workers; medium: 26-100 workers; large: more than 100 workers); and tenure dummies (up to 6 months; 7-12 months; 13-36 months; 37-72 months; more than 72 months). And $\varepsilon_{i t}$ is a conventional error term.

This corresponds to a first difference approach (Kramarz and Philippon 2001). If the treatment and control groups are structurally different, the estimates of $\beta$ will not have a causal 
interpretation of the minimum wage impact. In this case, they will only reflect the heterogeneity among these groups. Indeed, the cross-section analysis does not account specifically for the variations in the real minimum wage; rather, it shows how the conditional probability of maintaining the same employer varies among the different wage groups. Therefore, we cannot yet attribute to those policy options the variability in employment stability.

We go a step further to estimate a model that resembles a difference-in-differences approach. We use the panel dimension of the data and control for unobserved time-invariant heterogeneity in the treatment and control groups separately from the impact of the minimum wage. In order to do this we introduce an interaction term between the wage group indicators and the real change in the minimum wage.

The following panel data model with firm $(j)$ and year $(t)$ fixed-effects is estimated over the 2003-2010 period:

$$
y_{i j t}=\sum_{k=1}^{6}\left(\beta_{k}+\gamma_{k} \Delta W_{t}^{\text {min }}\right) D_{k, i j t-1}+X_{i j t-1} \theta+\alpha_{j}+\lambda_{t}+\varepsilon_{i j t},
$$

where all variables are defined as before and $\Delta W_{t}^{\text {min }}$ represents the percentage points variation in the real minimum wage in year $t$. The interaction term between the wage level, $D_{k, i j t-1}$, and the minimum wage variation, $\Delta W_{t}^{\text {min }}$, captures the impact on the probability of remaining employed in year $t$ at the different wage levels due to the minimum wage variation. The $\alpha$ terms capture the firm fixed-effects and $\lambda$ the year fixed-effects. Note that the specification imposes the mild hypothesis that individuals in the top wage quartile are not affected by variations in the real minimum wage.

\subsection{Match stability: First difference approach}

We consider the 8 cross-sections of matches for the period from 2003 to 2010 . The results are interpretable as long-term relationships, in that each match represents a cohort in different stages in the life cycle of the labor market. Additionally, over these years, the minimum wage changes were dramatically different, with real wage losses followed by large real wage gains (see Section 3). We present in Table 3 the results for 2003, 2007 and 2010.

TABLE 3; see page 23. 
A Portuguese forty-year-old male, working in a large services firm, in 2002, with more than 6 years of tenure and a wage falling in the top quartile had a 88 per cent probability of remaining employed in the same firm in 2003. Relatively to matches in the top quartile, the minimum wage group in 2002 was 6.8 p.p. less likely to keep the same job in 2003 (Table 3, column (1)). In other words, the probability of worker turnover for the minimum wage group is $19.1 \%$, i.e., $180 \%$ higher than that of the top quartile match. This result is not surprising in view of the evidence that low-wage matches have higher worker rotation rates (Centeno and Novo 2012).

The following group, composed of matches paying wages at least the new minimum wage, was 6.4 p.p. less likely to survive than top-wage matches, a result remarkably similar to the old minimum wage matches. The next wage-group, which is the first one not directly affected by the new minimum wage, is 0.3 p.p. more likely to survive than the previous group. The difference relative to the top quartile falls faster and monotonically for the other wage-groups.

We estimated this model using both a linear probability model and a probit model. As it can be seen in Table 1, the results are slightly larger for the probit model, but qualitatively they do not depend on the choice of the method. For computational reasons, related with the usage of firm fixed-effects, in the remaining of the paper, we report only the results of the linear probability model (Angrist and Pischke (2009) have a detailed discussion of linear probability vs. probit models).

\subsection{Match survival: Difference-in-differences approach}

The cross-section results gave us a first rough measure of how the probability of employment varies across the wage distribution. With panel data, we will be able to breakdown this probability into two factors, a wage-group specific component, and one due to the variation in the minimum wage. The latter is the one of interest for our analysis. Table 4 reports the panel data results. To simplify the interpretation of the results, the minimum wage growth variable was demeaned (the sample mean is $2 \%$ ). Henceforth, the coefficients should be interpreted as the impact of a real minimum wage increase close to $2 \%$.

TABLE 4; see page 24 .

The minimum wage increase is clearly binding in determining the success of matches. The marginal impact of changes in the minimum wage is strong among minimum-wage earners; 
they are more likely to terminate their current labor market relationship, about 0.74 p.p. for each percentage point increase in the minimum wage. In 2009, where the real minimum wage increased $6.6 \%$ (4.6 p.p. above the average), the probability of survival for a minimum wage match decreases by (an additional) 3.4 p.p.

This impact falls monotonically along the wage distribution, as in the first difference approach. It remains high for matches paying more than the old but less than the new minimum wage (a 0.5 p.p. reduction in the match survival probability) and reaches 0.1 p.p. for those in the 3rd wage quartile.

The main conclusion from these results highlights that match survival in year $t$ of year $t-1$ jobs with wages between the old and the new minimum wage is adversely affected by minimum wage increases. The overall impact on the whole labor market is rather sizable given the large share of the workforce in this wage range. In 2009, $17.6 \%$ of all matches paid less than the new minimum wage and in 2002 this figure was $12.1 \%$.

The new minimum wage imposes a binding exogenous constraint on firms. Firms must adjust their production process to accommodate this raise in labor costs. In doing so they adjust their wage bill: reducing the quantity of labor (number of workers and hours worked); the wages paid or a combination of both. We have seen that firms adjust downwards the amount of labor. To study the behavior of wages we use the same specification (equation (2)), changing only the dependent variable to the log difference between the real wage in years $t$ and $t-1$ (in percentage). Table 4 , column (2), reports the estimates of the percent impact on wage growth for each group of matches relatively to the top quartile. The more noticeable fact is that the marginal impact of a percentage point increase in the real minimum wage is positive for those below next year's minimum wage and zero for those just above it. Each percentage point increase in the minimum wage raises the wages in matches that paid the minimum wage in period $t$ by 0.63 p.p. Matches in the group between the new and old minimum wages increase their wages by 0.24 p.p.

The resulting wage elasticity of match survival is slightly larger than one for matches paying the old minimum wage $(-1.2)$ and close to 2 for matches with wages below the new minimum. These matches are more adversely affected by a one percentage point increase in the minimum wage as their wage gain is quite small, when compared with the change in match destruction. 
We conclude that, when compared with the 4th quartile, all wage-groups are affected, by the minimum wage increase, but to different degrees. We reject the equality of the impact below and above the new minimum wage. The minimum wage has a larger impact on low-wage earners.

\subsection{Match survival heterogeneity: Young workers and sector of activity}

It is a well-established fact in the literature that the minimum wage is more binding among lowskilled and young workers, those more prone to earn low wages due to the lower productivity and the low entry wages at the screening stage of the workers' career. Column (1) of Table 5 reports the model results considering the sub-sample of workers aged less than 25 years (the wage quartiles are re-defined for each of the sub-samples used). Overall, the results indicate that job stability of young workers is more sensitive to variations in the real minimum wage. This is particularly true for the group earning exactly the current year's minimum wage; for each percentage point increase in the minimum wage, the probability of keeping the same job falls 1.10 p.p. This is almost $50 \%$ higher than the effect estimated for the whole population of matches (0.74). In column (2), we see that the impact on real wages of the minimum wage variation is similar in magnitude to the previous estimates, but it is statistically nonsignificant for the group of matches paying just above next year's minimum wage. Together, these results imply a larger (in absolute value) elasticity among young minimum wage matches $(-1.6)$.

TABLE 5; see page 25.

The share of minimum wage matches varies across industries (Table 1). These differences reflect different skills, contract duration and the market pressure on wages. In industries with lower human capital requirements, the prevalence of minimum-wage earners is stronger, as it is in industries with high worker turnover. In addition, tradable goods sectors suffered during this period from increasing external competition which placed a strong downward pressure on wages. An exogenous increase in the minimum wage is expected to have a stronger impact in firms with a larger share of minimum wage matches. To study this possibility, we consider three sub-samples: manufacturing, construction, and services. Columns (4)-(12) present the estimates for the impact of the minimum wage increases on matches and wages. 
There are three noteworthy facts. First, the larger impacts on match stability occur in manufacturing and the smaller in the services sector. Second, in the case of manufacturing, the large magnitudes of the impact on match survival, which in the baseline model were observed for the two groups below next year's minimum wage, are extended to the wage groups below the median. Third, in the services sector the impact is significant only for matches paying the current minimum-wage.

\subsection{Employment effects of the minimum wage}

Hitherto, we have considered how changes in the minimum wage affect the probability of remaining employed in the same match. However, workers may search for a new job and labor demand may also react differently from one firm to the other. We hypothesize that these mitigating effects would deliver smaller impacts of the minimum wage in the probability of securing employment when compared with the probability of securing the current match. The results of the estimation are presented in Table 6 .

TABLE 6; see page 26.

As expected, column (1) of Table 6 presents larger coefficients (less negative) than the equivalent ones for the match analysis (Table 4). For minimum wage earners the probability of remaining employed decreases by about 0.56 p.p. for each percentage point of increase in the minimum wage. For instance, in 2009, the probability of remaining employed for a minimum wage earner decreases by (an additional) 2.6 p.p. Overall, in 2009, minimum-wage earners had a probability of remaining employed 9.8 p.p. (7.2 p.p. +2.6 p.p.) lower than a top quartile worker.

Our results are closer to those obtained for the US and the UK than for France. In particular, Currie and Fallick (1996) obtain an employment elasticity to changes in the minimum wage of -0.4 for the US, which is close to our estimate of -0.56 . The elasticities estimated by Abowd et al. (2000) are slightly larger for the US, but clearly larger for France. Machin, Manning and Rahman (2003) study the impact of the introduction of the minimum wage in the UK and find also a small impact on employment. The evidence gathered for Portugal is ambiguous. Using a legislative reform, which raised the minimum wage for workers aged 15 to 19 years, Portugal and Cardoso (2006) show that it resulted in a larger reduction of separations than in hirings. Using the same reform, Pereira (2003) reports a reduction in 
employment among such workers. The estimated employment-minimum wage elasticities in Pereira (2003) are slightly smaller than our estimates.

The minimum-wage-to-wage elasticity is 0.52 (columns (2)). Figure 5 plots all the marginal effects on wages and, apart from a rescaling, the shape of the curve is generally equivalent to Figure 3. This implies that increases in the real minimum wage are not innocuous for nonminimum-wage earners. The spillover on the other individuals' wages is negative, suggesting that firms adjust the other wage gains downwards to accommodate exogenous increases in the minimum wage. For those concerned with inequality, this outcome contributes towards a more uniform wage distribution. But as always, there might be too much of a good thing and the negative impact on employment must be also considered.

FIGURE 5; see page 20.

Table 6, column (3), reports the wage elasticities of employment of each group. The elasticity of minimum-wage earners is -1.1, indicating that for each percentage point increase in wages, employment decrease by slightly more than 1 percentage point. The elasticity among the group earning below next year's minimum wage is quite large, -5.3, resulting primarily from having a small wage variation due to the minimum wage and a negative impact on employment similar to the minimum-wage earners. As with match stability, this group suffers the most from increases in the minimum wage: large losses of total income.

\section{Conclusion}

The Portuguese economy provides an interesting setting to study the consequences of large minimum wage increases. We focus on the impact on match survival, which takes the analysis of the minimum wage inside the worker-firm relationship.

We provide evidence consistent with a strong direct impact of the minimum wage on match stability and on wages of low-paid individuals. The implied wage elasticity is larger than 1: these workers stand to lose with strong minimum wage increases. We also compute employment probability following a minimum wage increase. Interestingly, minimum wage earners have similar implied wage elasticities of match (individual firm) and employment (market) stability. However, this is obtained with a stronger sensitivity of a minimum wage increase on match stability and wages. Together, these results are consistent with firms 
operating on their labor demand schedule.

Given the low-wage mobility in the Portuguese labor market and the large share of workers directly affected by the minimum wage increase (reaching almost 18\%), these results call for a careful analysis of policies that interfere with low-wage employment, such as the unemployment insurance system.

Unemployment insurance acts as a search subsidy, reducing the liquidity constraint that workers face upon job loss. However, Centeno and Novo (2014) show that low-wage workers spend shorter periods in subsidized unemployment and react less to longer entitlement periods. Therefore, alleviating the liquidity constraints requires a front-loading of income support, for example by means of a higher replacement rate of wages rather than with longer entitlement periods. This potentiates the liquidity effect, allowing workers to search for better jobs.

An integrated set of policies should combine (i) an increase in the minimum wage, which may promote the formation of better matches in the economy (Acemoglu 2001), with (ii) an unemployment insurance system that effectively alleviates the liquidity restriction of the unemployed. A failure to extract these two virtuous mechanisms from these policies, coupled with low-wage mobility, which reduces the incentives to search for long periods of time, creates a career trap for low-wage workers.

\section{Acknowlegments}

We would like to thank António Antunes, Hugo Reis and participants at the SOLE 2012 and AIEL 2012 Annual Conferences for comments. Centeno and Novo acknowledge the financial support provided by FCT's grant PTDC/EGE-ECO/112177/2009. Opinions expressed herein do not necessarily reflect the views of the Banco de Portugal. Any errors are of our responsibility.

\section{Competing Interest}

The authors declare that they have no competing interests.

\section{Authors' Contributions}

The paper was purely a co-authorship project. All authors read and approved the final manuscript. 


\section{References}

Abowd, J., Kramarz, F., Margolis, D. and Philippon, T. (2000), The tail of two countries: Minimum wages and employment in France and the United States, Discussion Paper 300, IZA.

Acemoglu, D. (2001), 'Good jobs versus bad jobs', Journal of Labor Economics 19(1), 1-21.

Angrist, J. D. and Pischke, J.-S. (2009), Mostly Harmless Econometrics: An Empiricist's Companion, Princeton University Press.

Autor, D. H., Manning, A. and Smith, C. L. (2010), The contribution of the minimum wage to U.S. wage inequality over three decades: A reassessment, Working Paper 16533, NBER.

URL: $h t t p: / / w w w . n b e r . o r g / p a p e r s / w 16533$

Card, D. and Krueger, A. (1995), Myth and measurement: The new economics of the minimum wage, Princeton University Press.

Centeno, M. and Novo, A. (2012), 'Excess worker turnover and fixed-term contracts: Causal evidence in a two-tier system', Labour Economics 19(3), 320-328.

Centeno, M. and Novo, Á. A. (2014), 'Do low-wage workers react less to longer unemployment benefits? quasi-experimental evidence', Oxford Bulletin of Economics and Statistics 76(2), 185-207.

Currie, J. and Fallick, B. (1996), 'The minimum wage and the employment of youth evidence from the NLSY', Journal of Human Resources 31(2), 404-428.

Dube, A., Lester, T. W. and Reich, M. (2010), 'Minimum wage effects across state borders: Estimates using contiguous counties', The Review of Economics and Statistics 92(4), 945964.

Flinn, C. J. (1986), 'Wages and job mobility of young workers', The Journal of Political Economy pp. S88-S110.

Flinn, C. J. (2010), The minimum wage and labor market outcomes, MIT Press.

Freeman, R. (1996), 'The minimum wage as a redistributive tool', The Economic Journal pp. 639-649. 
Jovanovic, B. (1979), 'Job matching and the theory of turnover', The Journal of Political Economy 87(5), 972.

König, M. and Möller, J. (2009), 'Impacts of minimum wages: a microdata analysis for the german construction sector', International Journal of Manpower 30(7), 716-741.

Kramarz, F. and Philippon, T. (2001), 'The impact of differential payroll tax subsidies on minimum wage employment', Journal of Public Economics 82(1), 115-146.

Lazear, E. and Shaw, K. (2007), 'Personnel economics: The economist's view of human resources', The Journal of Economic Perspectives 21(4), 91-114.

Machin, S., Manning, A. and Rahman, L. (2003), 'Where the minimum wage bites hard: Introduction of minimum wages to a low wage sector', Journal of the European Economic Association 1(1), 154-180.

Neumark, D., Schweitzer, M. and Wascher, W. (2004), 'Minimum wage effects throughout the wage distribution', The Journal of Human Resources 39(2), 425-450.

Pereira, S. (2003), 'The impact of minimum wages on youth employment in Portugal', European Economic Review 47(2), 229-244.

Pissarides, C. (2000), Equilibrium unemployment theory, the MIT press.

Portugal, P. and Cardoso, A. (2006), 'Disentangling the minimum wage puzzle: An analysis of worker accessions and separations', Journal of the European Economic Association $4(5), 988-1013$.

Topel, R. and Ward, M. (1992), 'Job mobility and the careers of young men', Quarterly Journal of Economics 107, 439-479. 


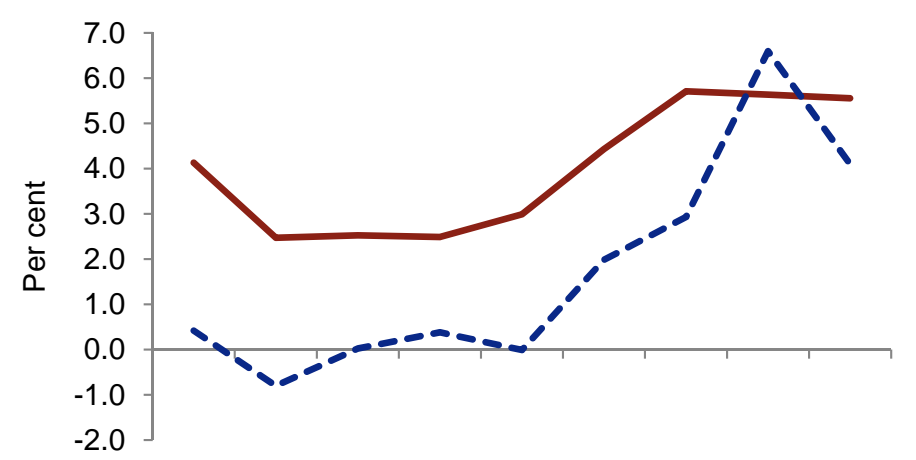

200220032004200520062007200820092010

Nominal rate of change $\ldots-$ Real rate of change

Figure 1: Minimum wage nominal and real growth rates
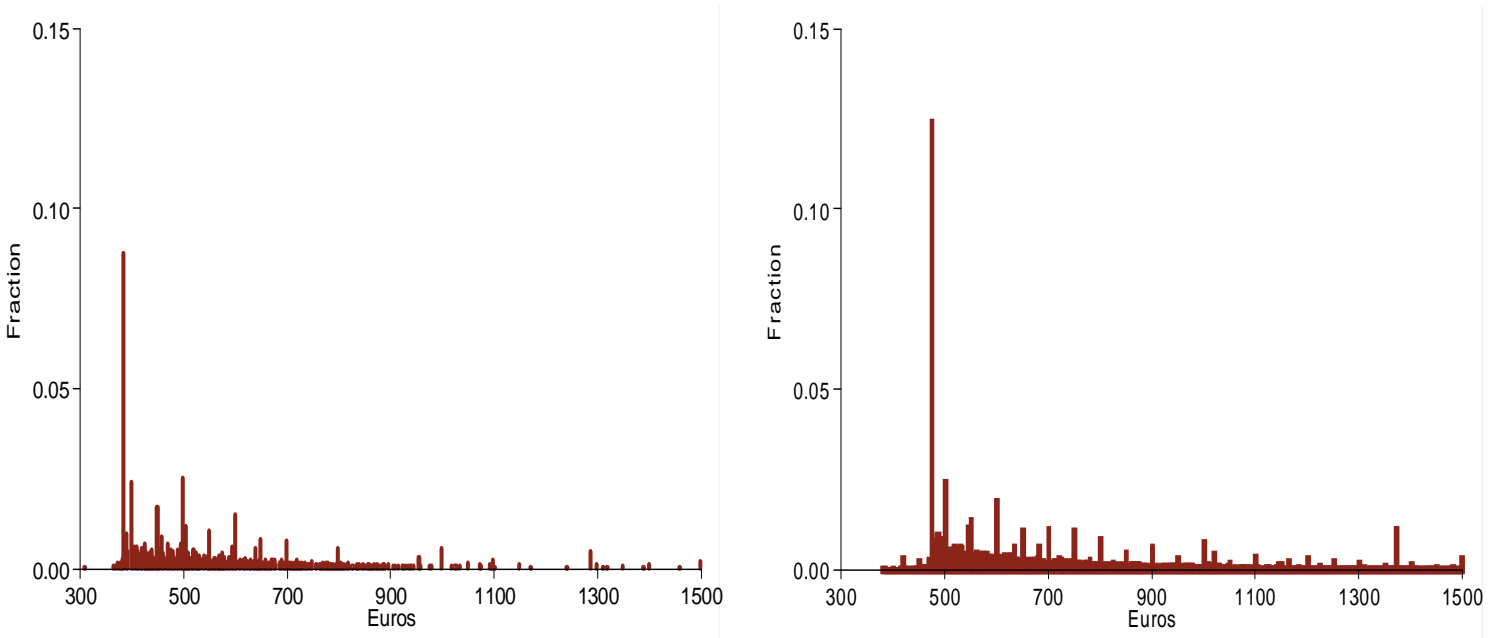

Figure 2: Wage distributions in 2006 and 2010 Note: Social Security data. 


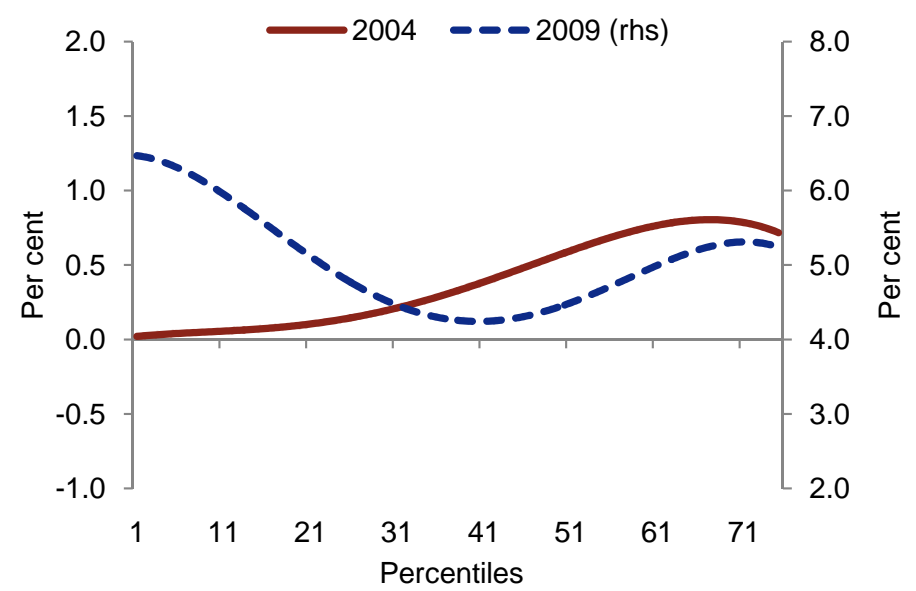

Figure 3: Real wage growth rate by percentile of the wage distribution Note: Social Security data.

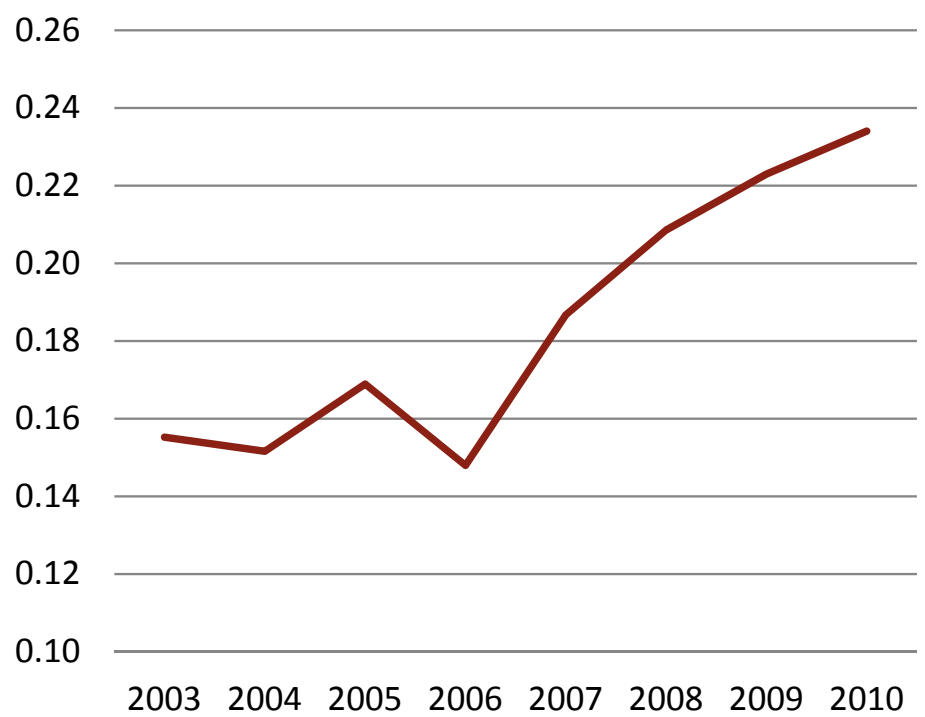

Figure 4: Share of minimum wage workers in transitions from employment to non-employment Note: Social Security data. Transitions are computed as the share of workers employed in year $\mathrm{t}$ and non-employed in year $\mathrm{t}+1$. 


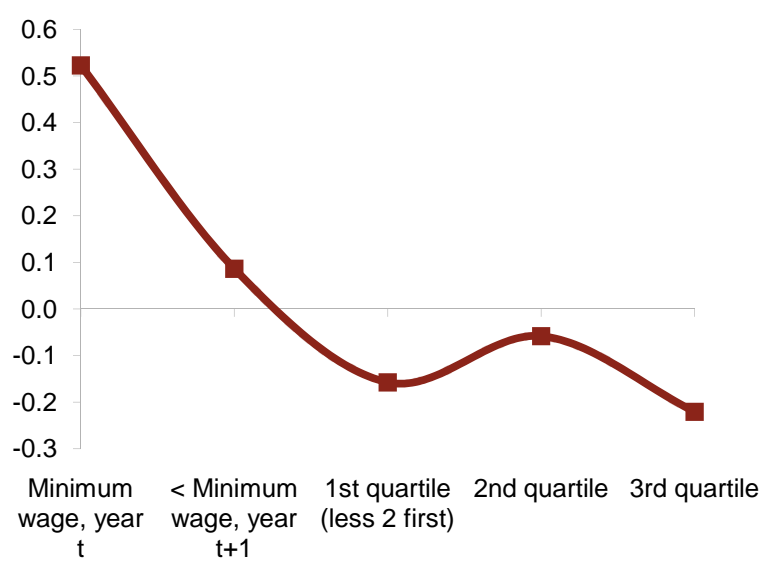

Figure 5: Marginal impact on wages of the minimum wage by wage-level Note: Social Security data. The figure plots the coefficient on wages, from the wage regression in Table 6, column (2). 
Table 1: Matches descriptive statistics

\begin{tabular}{lccc}
\hline & 2002 & 2006 & 2010 \\
\hline Wage distribution statistics & & & \\
Minimum wage & 348.00 & 385.90 & 475.00 \\
Average wage & 703.39 & 790.52 & 921.79 \\
Median wage & 500.00 & 575.75 & 660.00 \\
Kaitz index - Average wage & 0.49 & 0.49 & 0.52 \\
Kaitz index - Median wage & 0.70 & 0.67 & 0.72 \\
& & & \\
Share of minimum wage matches & & & \\
Total & 7.7 & 7.5 & 12.4 \\
Male & 5.5 & 5.2 & 9.4 \\
Female & 10.5 & 10.4 & 16.0 \\
& & & \\
15-24 years & 14.3 & 15.7 & 24.5 \\
25-34 years & 6.8 & 6.7 & 11.5 \\
>34 years & 6.0 & 6.2 & 11.3 \\
Manufacturing & & & \\
Construction & 6.7 & 8.4 & 15.4 \\
Services & 6.4 & 5.9 & 13.2 \\
& 8.4 & 7.5 & 11.4 \\
Number of matches & & & \\
Total & & & \\
Minimum wage & $2,104,240$ & $2,222,559$ & $2,273,310$ \\
Less than next year's minimum wage & 93,988 & 148,740 & - \\
\hline Notes: Social Security data & 167,240 & 282,771 \\
\hline
\end{tabular}

Notes: Social Security data. The share of minimum wage earners is computed using a 2-euro interval centered on the legal minimum wage (minimum wage $+/-1$ euro). 
Table 2: Transition matrices, averages for each period

\begin{tabular}{lccc}
\hline \multirow{2}{*}{ Origin state } & \multicolumn{2}{c}{ Destination state } \\
& $\begin{array}{c}\text { Minimum } \\
\text { wage earner }\end{array}$ & $\begin{array}{c}\text { Abt quartile } \\
\text { 1st quartile }\end{array}$ \\
\hline & & $2002-2006$ \\
Minimum wage earner & 0.747 & 0.205 & 0.048 \\
Less than next year's minimum wage & 0.252 & 0.680 & 0.068 \\
1st quartile & 0.009 & 0.859 & 0.133 \\
Above 1st quartile & 0.001 & 0.057 & 0.942 \\
& & & \\
& & $2007-2010$ & \\
Minimum wage earner & 0.782 & 0.173 & 0.045 \\
Less than next year's minimum wage & 0.318 & 0.605 & 0.077 \\
1st quartile & 0.017 & 0.830 & 0.153 \\
Above 1st quartile & 0.002 & 0.059 & 0.939 \\
\hline
\end{tabular}

Notes: Social Security data, 2002-2010. Each cell presents the average annual empirical transition rate between the original state (in period $t$ ) and the destination state (in period $t+1$ ). All workers retaining employment are used in the computation, each row summing one. 
Table 3: Probit and linear probability models: Year-by-year estimates

\begin{tabular}{|c|c|c|c|}
\hline & $2002 / 03$ & $2006 / 07$ & $2009 / 10$ \\
\hline & \multicolumn{3}{|c|}{ Linear probability model } \\
\hline Wage level indicator: & & & \\
\hline Current minimum wage & $\begin{array}{c}-6.83 \\
(0.000)\end{array}$ & $\begin{array}{c}-8.19 \\
(0.000)\end{array}$ & $\begin{array}{c}-7.25 \\
(0.000)\end{array}$ \\
\hline Less than next year's minimum wage & $\begin{array}{c}-6.36 \\
(0.000)\end{array}$ & $\begin{array}{c}-9.69 \\
(0.000)\end{array}$ & $\begin{array}{c}-7.54 \\
(0.000)\end{array}$ \\
\hline More than next year's minimum wage but less than 1st quartile & $\begin{array}{c}-6.07 \\
(0.000)\end{array}$ & $\begin{array}{c}-7.88 \\
(0.000)\end{array}$ & $\begin{array}{c}-5.45 \\
(0.000)\end{array}$ \\
\hline 2nd quartile & $\begin{array}{c}-4.73 \\
(0.000)\end{array}$ & $\begin{array}{c}-6.02 \\
(0.000)\end{array}$ & $\begin{array}{c}-4.40 \\
(0.000)\end{array}$ \\
\hline \multirow[t]{2}{*}{ 3rd quartile } & $\begin{array}{c}-2.47 \\
(0.000)\end{array}$ & $\begin{array}{c}-3.44 \\
(0.000)\end{array}$ & $\begin{array}{c}-1.99 \\
(0.000)\end{array}$ \\
\hline & \multicolumn{3}{|c|}{ Probit model } \\
\hline \multicolumn{4}{|l|}{ Wage level indicator: } \\
\hline Current minimum wage & $\begin{array}{c}-7.48 \\
(0.000)\end{array}$ & $\begin{array}{c}-9.21 \\
(0.000)\end{array}$ & $\begin{array}{c}-7.81 \\
(0.000)\end{array}$ \\
\hline Less than next year's minimum wage & $\begin{array}{c}-7.10 \\
(0.000)\end{array}$ & $\begin{array}{l}-10.76 \\
(0.000)\end{array}$ & $\begin{array}{c}-8.38 \\
(0.000)\end{array}$ \\
\hline More than next year's minimum wage but less than 1st quartile & $\begin{array}{c}-6.78 \\
(0.000)\end{array}$ & $\begin{array}{c}-8.88 \\
(0.000)\end{array}$ & $\begin{array}{c}-6.07 \\
(0.000)\end{array}$ \\
\hline 2nd quartile & $\begin{array}{c}-5.27 \\
(0.000)\end{array}$ & $\begin{array}{c}-6.79 \\
(0.000)\end{array}$ & $\begin{array}{c}-5.02 \\
(0.000)\end{array}$ \\
\hline 3rd quartile & $\begin{array}{c}-2.79 \\
(0.000)\end{array}$ & $\begin{array}{c}-4.08 \\
(0.000)\end{array}$ & $\begin{array}{c}-2.41 \\
(0.000)\end{array}$ \\
\hline Number of observations & $2,104,240$ & $2,222,559$ & $2,280,091$ \\
\hline
\end{tabular}

Sources: Social Security data. Notes: p-values in parentheses. The remaining control variables included in the model are omitted from the Table; see text for the full set of variables included. Coefficients were multiplied by 100 to be interpretable as the percentage change in the probability of remaining employed in the same firm between two consecutive years for each level of the initial wage relatively to those with wages in the top quartile. For instance, an individual earning the minimum wage in 2002 will be 6.8 p.p. less likely to remain employed in the same firm in 2003 than an individual with a wage in the top quartile, but otherwise equal (age, gender, industry, etc). 
Table 4: Match status and wages: Firm fixed effects linear probability

\begin{tabular}{|c|c|c|c|}
\hline & $\begin{array}{l}\text { Match } \\
(1)\end{array}$ & $\begin{array}{l}\text { Wages } \\
(2)\end{array}$ & $\begin{array}{l}\text { Elasticity } \\
(3)=(1) /(2)\end{array}$ \\
\hline \multicolumn{4}{|l|}{ Wage level indicator: } \\
\hline$W_{t-1}=W_{t-1}^{\min }$ & $\begin{array}{c}-7.22 \\
(0.000)\end{array}$ & $\begin{array}{c}12.53 \\
(0.000)\end{array}$ & \\
\hline$W_{t-1}<W_{t}^{\min }$ & $\begin{array}{l}-6.26 \\
(0.000)\end{array}$ & $\begin{array}{c}11.43 \\
(0.000)\end{array}$ & \\
\hline$W_{t}^{m i n} \leq W_{t-1} \leq Q_{.25}\left(W_{t-1}\right)$ & $\begin{array}{l}-4.65 \\
(0.000)\end{array}$ & $\begin{array}{c}9.42 \\
(0.000)\end{array}$ & \\
\hline$W_{t-1} \in Q_{.5}\left(W_{t-1}\right)$ & $\begin{array}{c}-2.52 \\
(0.000)\end{array}$ & $\begin{array}{c}7.50 \\
(0.000)\end{array}$ & \\
\hline$W_{t-1} \in Q_{.75}\left(W_{t-1}\right)$ & $\begin{array}{l}-0.79 \\
(0.000)\end{array}$ & $\begin{array}{c}4.58 \\
(0.000)\end{array}$ & \\
\hline \multicolumn{4}{|l|}{$\Delta W_{t}^{\text {min,real }} \times$ Wage level indicator: } \\
\hline$W_{t-1}=W_{t-1}^{\min }$ & $\begin{array}{c}-0.74 \\
(0.000)\end{array}$ & $\begin{array}{c}0.63 \\
(0.000)\end{array}$ & -1.18 \\
\hline$W_{t-1}<W_{t}^{\min }$ & $\begin{array}{c}-0.47 \\
(0.000)\end{array}$ & $\begin{array}{c}0.24 \\
(0.000)\end{array}$ & -1.98 \\
\hline$W_{t}^{\min } \leq W_{t-1} \leq Q_{.25}\left(W_{t-1}\right)$ & $\begin{array}{c}-0.27 \\
(0.000)\end{array}$ & $\begin{array}{c}0.00 \\
(0.891)\end{array}$ & - \\
\hline$W_{t-1} \in Q_{.5}\left(W_{t-1}\right)$ & $\begin{array}{l}-0.30 \\
(0.000)\end{array}$ & $\begin{array}{c}0.00 \\
(0.675)\end{array}$ & - \\
\hline$W_{t-1} \in Q .75\left(W_{t-1}\right)$ & $\begin{array}{l}-0.09 \\
(0.000)\end{array}$ & $\begin{array}{l}-0.17 \\
(0.000)\end{array}$ & 0.54 \\
\hline No. of observations & & $13,239,530$ & \\
\hline Other control variables & \multicolumn{2}{|c|}{- Yes - } & \\
\hline
\end{tabular}

\footnotetext{
Notes: Social Security data, 2002-2010. p-values in parentheses. $Q_{.75}\left(W_{t-1}\right)$ stands for the 3rd quartile of year's $t-1$ wage distribution; similarly for other quartiles. See text for the full set of variables included. Conditional on a $2 \%$ increase in the real minimum wage, the coefficients were multiplied by 100 to be interpretable as the percentage change in the probability of remaining employed between two consecutive years for each level of the initial wage relatively to those with wages in the top quartile. For instance, an individual earning the minimum wage in a particular year will be 7.2 percentage points less likely to remain in the same match in the following year than an individual with a wage in the top quartile, but otherwise equal (age, gender, industry, etc). In addition, for each percentage point above $2 \%$ in the growth rate of the minimum wage, the probability of staying in the same match further decreases by 0.74 percentage points.
} 


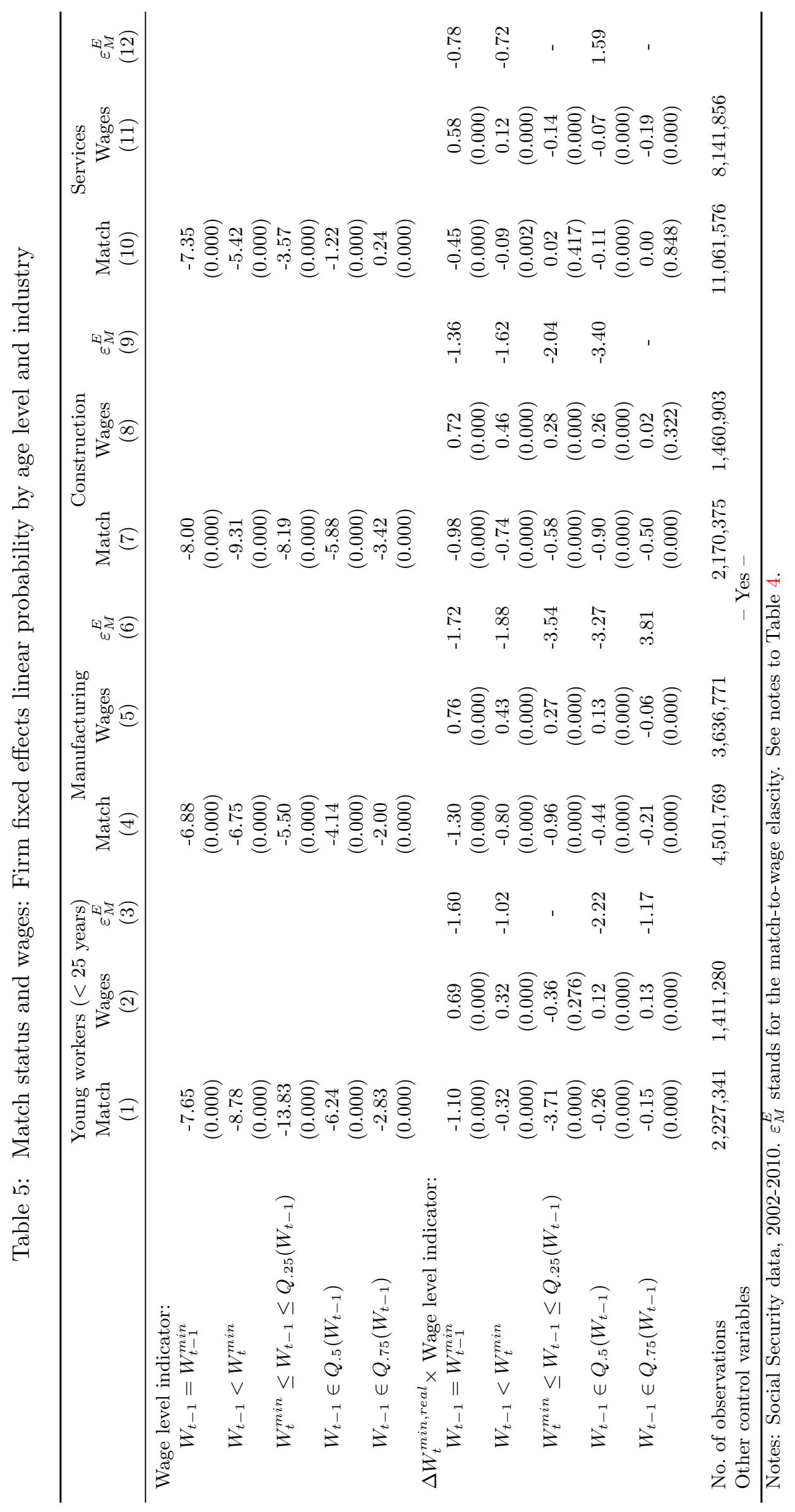


Table 6: Employment status and wages: Firm fixed effects linear probability

\begin{tabular}{|c|c|c|c|}
\hline & $\begin{array}{c}\text { Employment } \\
\text { (1) }\end{array}$ & $\begin{array}{c}\text { Wages } \\
(2)\end{array}$ & $\begin{array}{l}\text { Elasticity } \\
(3)=(1) /(2)\end{array}$ \\
\hline \multicolumn{4}{|l|}{ Wage level indicator: } \\
\hline$W_{t-1}=W_{t-1}^{\min }$ & $\begin{array}{c}-7.21 \\
(0.000)\end{array}$ & $\begin{array}{c}15.80 \\
(0.000)\end{array}$ & \\
\hline$W_{t-1}<W_{t}^{\min }$ & $\begin{array}{l}-5.88 \\
(0.000)\end{array}$ & $\begin{array}{l}14.69 \\
(0.000)\end{array}$ & \\
\hline$W_{t}^{\min } \leq W_{t-1} \leq Q_{.25}\left(W_{t-1}\right)$ & $\begin{array}{l}-4.42 \\
(0.000)\end{array}$ & $\begin{array}{l}12.05 \\
(0.000)\end{array}$ & \\
\hline$W_{t-1} \in Q_{.5}\left(W_{t-1}\right)$ & $\begin{array}{l}-2.56 \\
(0.000)\end{array}$ & $\begin{array}{c}9.22 \\
(0.000)\end{array}$ & \\
\hline$W_{t-1} \in Q .75\left(W_{t-1}\right)$ & $\begin{array}{c}-1.11 \\
(0.000)\end{array}$ & $\begin{array}{c}5.35 \\
(0.000)\end{array}$ & \\
\hline \multicolumn{4}{|l|}{$\Delta W_{t}^{\text {min,real }} \times$ Wage level indicator: } \\
\hline$W_{t-1}=W_{t-1}^{\min }$ & $\begin{array}{l}-0.56 \\
(0.000)\end{array}$ & $\begin{array}{c}0.52 \\
(0.000)\end{array}$ & -1.08 \\
\hline$W_{t-1}<W_{t}^{\min }$ & $\begin{array}{l}-0.45 \\
(0.000)\end{array}$ & $\begin{array}{c}0.09 \\
(0.000)\end{array}$ & -5.26 \\
\hline$W_{t}^{\min } \leq W_{t-1} \leq Q_{.25}\left(W_{t-1}\right)$ & $\begin{array}{l}-0.26 \\
(0.000)\end{array}$ & $\begin{array}{l}-0.16 \\
(0.000)\end{array}$ & 1.64 \\
\hline$W_{t-1} \in Q_{.5}\left(W_{t-1}\right)$ & $\begin{array}{l}-0.31 \\
(0.000)\end{array}$ & $\begin{array}{l}-0.06 \\
(0.000)\end{array}$ & 5.23 \\
\hline$W_{t-1} \in Q_{.75}\left(W_{t-1}\right)$ & $\begin{array}{c}-0.17 \\
(0.000)\end{array}$ & $\begin{array}{c}-0.22 \\
(0.000)\end{array}$ & 0.76 \\
\hline No. of observations & $17,377,525$ & $14,721,929$ & \\
\hline Other control variable & $-\mathrm{Ye}$ & & \\
\hline \multicolumn{4}{|c|}{$\begin{array}{l}\text { Notes: Social Security data, } 2002-2010 \text {. p-values in parentheses. } Q .75\left(W_{t-1}\right) \text { stands for } \\
\text { the 3rd quartile of year's } t-1 \text { wage distribution; similarly for other quartiles. See text } \\
\text { for the full set of variables included. Conditional on a } 2 \% \text { increase in the real minimum } \\
\text { wage (roughly, the average in the period), the coefficients were multiplied by } 100 \text { to be } \\
\text { interpretable as the percentage change in the probability of remaining employed between } \\
\text { two consecutive years for each level of the initial wage relatively to those with wages in } \\
\text { the top quartile. For instance, an individual earning the minimum wage in a particular } \\
\text { year will be } 7.2 \text { percentage points less likely to remain employed in the following year than } \\
\text { an individual with a wage in the top quartile, but otherwise equal (age, gender, industry, } \\
\text { etc). In addition, for each percentage point above } 2 \% \text { in the growth rate of the minimum } \\
\text { wage, employment probability decreases by } 0.56 \text { percentage points. }\end{array}$} \\
\hline
\end{tabular}

